\author{
繰り返しパルスレーザー用 \\ 誘導ブリルアン散乱位相共役鏡の熱効果 \\ 吉田 英次, 大久保 彰律*, 藤田 尚徳, 中塚 正大 \\ 大阪大学レーザー核融合研究センター（テ565-0871 大阪府吹田市山田丘2-6） \\ *パイオニア (株) 総合研究所 (テ350-2288 埼玉県鶴ケ島市富士見6-1-1)
}

\title{
Thermally Induced Effects of Stimulated Brillouin Scattering via Phasc-Conjugation Mirror for Repetitive Laser Pulse
}

\author{
Hidetsugu YOSHIDA, Akinori OHKUBO, ${ }^{*}$ Hisanori FUJITA, and Masahiro NAKATSUKA \\ Institute of Laser Engineering, Osaka University, 2-6 Yamada-oka, Suita, Osaka 565-0871 \\ *Corporate Research, Pioneer Corporation, 6-1-1 Fujimi; Tsurugashima-shi, Saitama 350-2288
}

(Received October 17, 2000)

\begin{abstract}
We designed and demonstrated two new schemes to improve the performance of stimulated Brillouin scattering (SBS) cells for a high average power laser. By introducing a lamellar flow cell, thermally induced defocusing and convection via laser light absorption were removed. By inserting a rotational wedge plate, the spot was rotated in time and locate heat sources were diffused. As a result, the SBS reflectivity and fidelity were improved dramatically with acetone. Using the cell, the operational power can be improved by as much as several hundred times the closed-type. If a medium with a small absorption coefficient such as heavy fluorocarbons is used, the phase conjugate performance enables the incident power to reach a $\mathrm{kW}$ level.
\end{abstract}

Key Words: High average power laser, Phase conjugation mirror, Stimulated Brillouin scattering (SBS), Thermal defocusing, Liquid circulation

1.はじめに

近年, LD励起固体レーザーの研究が急激に進展し, 数 $\mathrm{kW}$ レベルの高平均出力で効率約 $20 \%$ 達成された1).しかし ながら, LD励起固体レーザーの高出力動作においても, LD 光の媒質への熱負荷の影響によりビーム品質の低下は避 けられず, 波面補償光学システムの採用は必要不可欠であ る. 代表的な波面補償光学素子には, (1) 反射鏡やレンズ等 の表面形状をアクチュエーターを用いて機械的に制御し, 波面の位相を補正するアダプティブオプティクス2)と,(2) 入射電界が非線形媒質 (気体, 液体, 固体等) 中で誘起する 三次の非線形現象により, 入射電界の全空間位相を瞬時に 反転し, 共役波面を発生する誘導ブリルアン散乱(以下 SBS $)^{3)}$ による方法がある.アダプティブオプティクス法 は, 高速のフィードバック制御が必要であり, システムコ ストが高価になり,小型レーザー装置にはあまり使用され ていない. 補償光学と位相共役に関しては, J. Roddier ${ }^{4)}$, 植田 ${ }^{5)}$ とH. Wang ${ }^{6)}$ ら解説記事が報告されている.

一方, SBSによる位相共役光の発生は高ピークレーザー を励起光とし,レーザー光をSBS媒質に集光するだけで容 易に高い反射率を得ることが可能である。しかしながら， レーザー強度の増加により(1)自己集束, (2)レーザー誘起 絶縁破壊, (3) 誘導ラマン散乱および(4) 共役波以外の雑音
となる非共役波の増幅等の不要な現象, (5)SBS媒質の熱光 学効果などの種々の問題により励起入力が制限される. SBS媒質の熱光学効果によるビーム忠実度の低下に関して は，メタンガスを用いたOttuschらによる実験7)，および Andreevらによる高繰り返しレーザーにおける液体媒質に ついて報告8)があるが,これらの報告では,忠実度を向上さ せる方法については十分な検討を行っていない.

本論文では, 高平均出力の励起レーザー光に伴うSBS液 体媒質内での相互作用領域の局所的熱発生による熱拡散 効果を詳細に調べ, 高平均出カレーザー用SBS位相共役波 特性を向上させる方法を実験的に検討した結果について 述べる。

\section{2. 封じ切り型液体 SBS 媒質の選定基準}

高平均入力動作において, 液体SBS位相共役鏡内の集光 点付近では, 局所的なレーザー光吸収による温度勾配を発 生する。このため, 集光点付近は熱的ビーム拡散が発生す るため集光強度が低下し, SBS反射率が低下する9). また, 液体の温度差による対流により, セル内の集光スポットは 乱れて分離するため, 同一位相から共役波増幅ができず ビーム忠実度が低下する ${ }^{10)}$ 。よって, 高繰り返し動作用封 じ切り型SBSセルでは, 励起波長での吸収係数が小さく, 熱 
拡散時間の速い媒質を選択する必要がある。

屈折率温度依存係数 $\mathrm{d} n / \mathrm{d} T$ が負の媒質に単一横モードパ ルスを入射した場合, 熱レンズ効果は, 回折限界集光スポッ 卜径内のエネルギー強度が $1 / 2$ に減少する熱的ビーム発散 の臨界エネルギー $E_{\mathrm{cr}}$ によって特徴づけられる。臨界エネ ルギーは,

$$
E_{\mathrm{cr}}=\frac{2 \pi \cdot \rho \cdot C}{\left|\frac{\partial n}{\partial T}\right| \cdot \alpha \cdot\left(\frac{2 \pi}{\lambda}\right)^{2}}
$$

で表される ${ }^{8)}$ 。ここに, $\lambda$ はレーザー波長, $\rho, C, \alpha, T, n$ はそ れぞれ媒質の密度, 比熱, 吸収係数, 温度および屈折率であ る。

液体媒質を用いてSBS反射を発生させるには，入射パ ワー $P_{\mathrm{in}}$ はSBS発生閾值パワー $P_{\mathrm{th}}$ を越えなければならな い. 一方, 回折限界の発散角の入射レーザー光(パルス幅 $\tau_{\mathrm{L}}$ ） $\mathrm{SBS}$ 媒質に集光した時, 集光ウェストを通過する透過 エネルギー $E_{\mathrm{tr}}$ は, SBS閾值パワーとパルス幅の積 $P_{\mathrm{th}} \cdot \tau_{\mathrm{L}}$ と

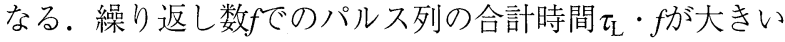
場合, 集光ウェストを透過する全エネルギー $E_{\mathrm{tr}}\left(=P_{\mathrm{th}} \cdot \tau_{\mathrm{L}} \cdot\right.$ f) は $E_{\mathrm{cr}}$ を越えることになる。この現象は $\tau_{\mathrm{L}} \cdot f か ゙$, 臨界パル ス幅 $\tau_{\mathrm{cr}}=E_{\mathrm{cr}} / P_{\mathrm{th}}$ を越えた時に発生する。例えば, 臨界エネ ルギー $E_{\mathrm{cr}}=10 \mathrm{~J}, \mathrm{SBS}$ 発生閾值 $P_{\mathrm{th}}=100 \mathrm{~kW}$ の液体を用いた 時, 臨界パルス幅 $\tau_{\mathrm{cr}}$ は $100 \mu \mathrm{s}$ となり, パルス幅 $\tau_{\mathrm{p}}=20 \mathrm{~ns}$ での 繰り返し周波数 $f$ は $5 \mathrm{kHz}$ まで可能である。また，(1)式にお ける液体の熱物性值Aは,ほほ同じであり,(1)より臨界パ ルス幅 $\tau_{\mathrm{cr}}[\mathrm{s}]$ は

$$
\tau_{\mathrm{cr}}=\frac{E_{\mathrm{cr}}}{P_{\mathrm{th}}}=\frac{A}{\alpha \cdot P_{\mathrm{th}}}
$$

と表すことができる。例えば,フロリナートFC-75の場合， 励起波長 $1.06 \mu \mathrm{m}$, 密度 $1.77\left(\mathrm{~g} / \mathrm{cm}^{3}\right)$, 比熱 $1.05(\mathrm{~J} / \mathrm{gK}), \mathrm{d} n / \mathrm{d} T=$ $-4.2 \times 10^{-4}\left(\mathrm{~cm}^{-1}\right)$ から, 熱物性值 $A=7.9 \times 10^{-6}(\mathrm{~J} / \mathrm{cm})$ である. 四塩化物やアセトンも $6 \times 10^{-6}(\mathrm{~J} / \mathrm{cm})$ 程度である。発生閾 值パワー $P_{\mathrm{th}}$ はSBS利得係数によって異なるが, 液体の場合 $100 \mathrm{~kW}$ 程度であり, 臨界パルス時間は吸収係数 $\alpha$ にきく 依存する. 例えば, 吸収係数 $\alpha=1 \times 10^{-6} \mathrm{~cm}^{-1}$, 熱物性值 $A=$ $5 \times 10^{-6}(\mathrm{~J} / \mathrm{cm})$ の液体の臨界パルス時間 $\tau_{\mathrm{cr}}$ は $60 \mu \mathrm{s}$ となる。

繰り返しレーザー光によるSBSセル内の強い熱光学効果 の防止を考慮する場合, 集光点のウエストでの熱拡散時間 $\tau_{\mathrm{d}}$ が $\tau_{\mathrm{cr}} / f \cdot \tau_{\mathrm{L}}$ 值より小さい時は, 熱的発散は無視できる。熱 拡散時間 $\tau_{\mathrm{d}}$ はレンズの焦点スポットの2乗 $d^{2}\left(\mathrm{~cm}^{2}\right)$ と熱拡散 率 $D\left(\mathrm{~cm}^{2} / \mathrm{s}\right)$ によって $\tau_{\mathrm{d}}=d^{2} / D て ゙$ 表される。例えば, 波長 $1.06 \mu \mathrm{m}$ の回折限界ビーム (口径 $10 \mathrm{~mm}$, 焦点距離 $f=100 \mathrm{~mm}$ ) をFC-75液体に集光した場合, $d^{2}=1.6 \times 10^{-6} \mathrm{~cm}^{2}, D=3.7 \times$ $10^{-4} \mathrm{~cm}^{2} / \mathrm{s}$ であり, 熱拡散時間 $\tau_{\mathrm{d}}$ は $4.3 \mathrm{~ms}$ である。よって, $\mathrm{kHz}$ 程度までの繰り返しを考えた高平均出力用SBS位相共役鏡 は, 短い焦点距離レンズの使用と吸収係数の小さく, 熱拡 散時間の短い媒質の選択により可能である。代表的な液 体SBS媒質の熱拡散率と臨界エネルギーの関係をFig.1に示 す。高平均出力用液体SBS媒質としては, 臨界エネルギー の大きい $\mathrm{CCl}_{4}, \mathrm{GeCl}_{4}, \mathrm{TiCl}_{4}, \mathrm{SiCl}_{4}, \mathrm{SnCl}_{4}$ 等のル㙉化系化合 物が優れている。しかしながら, 取り扱いに注意を要し, 不

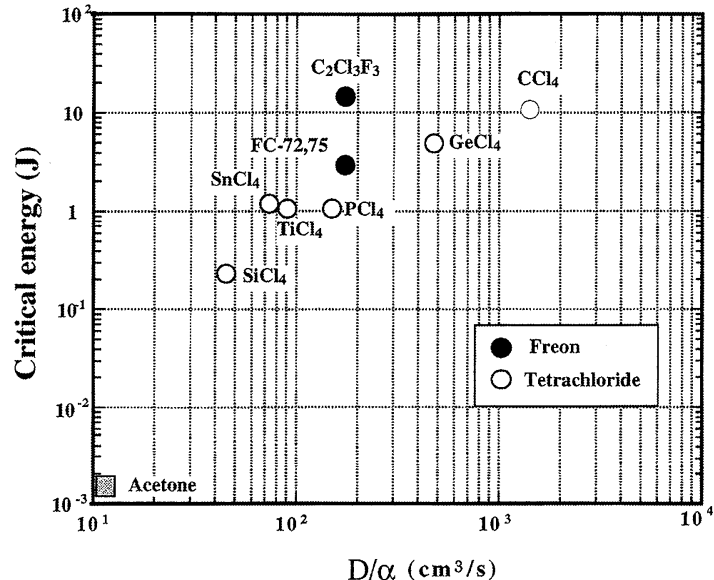

Fig.1 Thermal critical energy of several liquid media as a function of a ratio of the thermal diffusion coefficient, D to an absorption coefficient, $\alpha$.

純物除去が難しく, 含有不純物等によりレーザーブレーク ダウンが発生すると, 金属元素のイオン化によって吸収が 増加し, 現状では臨界エネルギーまでの動作は困難であ る. 一方, フレオン系化合物の中で $\mathrm{C}_{2} \mathrm{Cl}_{3} \mathrm{~F}_{3}$ (Freon113)は四 塩化系化合物と同等のSBS性能を有するが, 大気オゾン層 破壊から使用が規制され，現在は販売されていない。フッ 化炭素系化合物であるフロリナートFC-72,75 (3M商品 名) 11-13) は, 紫外から赤外域まで低吸収のため臨界エネル ギーが高く, 波長 $1 \mu \mathrm{m}$, パルス幅 $1 \mathrm{~ns}$ で $100 \mathrm{GW} / \mathrm{cm}^{2}$ 以上の高 レーザー耐力をもち, 化学的に非常に安定で取り扱い上安 全な液体である。

\section{3. 液体 SBS 媒質の熱光学効果低減の実験}

\section{1 封じ切りセルの熱光学効果}

SBS媒質のレーザー光吸収熱により集光点での屈折率変 化が生じた場合, 反射率の低下と共に反射ビーム忠実度は 大幅に低下する.SBS媒質の熱光学効果をFig.2の実験配置 によって測定した。SBSセル入射側に設置された $f=$ $150 \mathrm{~mm}$ の集光レンズを通過したHe-Neレーザープローブ光 は, 出射側の $f=150 \mathrm{~mm}$ のレンズで平行ビームとなる。 セ ルを透過した励起YAGレーザー光はダイクロイックミ ラー $(1.06 \mu \mathrm{m}$ 光反射, $0.63 \mu \mathrm{m}$ 光透過 $)$ にり分離される. 励 起レーザー光と同一光路上にアライメントされた $\mathrm{He}-\mathrm{Ne}$ レーザー光の集光点像を $f=1000 \mathrm{~mm}$ の集光レンズを用い て, CCDカメラによって観測した。励起光によるSBSセル 内の集光点付近のスポット径の増加や分離等の変化は, SBS反射率やビーム忠実度を大幅に低下することが観測さ れており ${ }^{9)}$, セル内の集光点付近の遠視野像を観測した。 プローブレーザーには, 測定の容易性から連続発振のHeNeレーザーを使用した.SBS液体の屈折率の波長分散効果

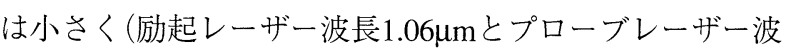
長 $0.63 \mu \mathrm{m})$, 光吸収による屈折率変化量の方が大きいた め, プローブ光による観測は問題とならない. 励起レー ザーけ,ノーマルパルス発振YAGレーザー（最大繰り返し 周波数 $50 \mathrm{~Hz}$, 出力 $30 \mathrm{~W})$ であり, SBS効果による反射はみら 


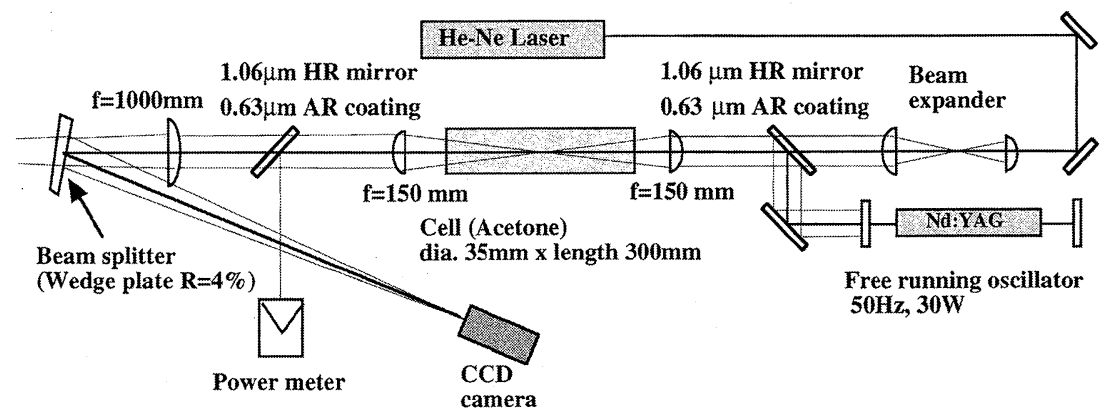

Fig.2 Experimental layout for the laser induced thermal effect measurement.

れず, 熱源として用いた。ダイクロイックミラーにより分 離観測したSBSセルからのYAGレーザー光の透過パワー から,媒質による吸収パワーを求めた. SBS媒質には, 波長 $1.06 \mu \mathrm{m}$ での吸収係数が $1 \times 10^{-2} \mathrm{~cm}^{-1}$ と大きく, 熱光学効果が 顕著にみられるアセトンを用いた。

Fig.3は励起レーザーエネルギー $80 \mathrm{~mJ} / \mathrm{pulse}$, 繰り返し周 波数 $3 \mathrm{~Hz}$ の時の透過He-Neレーザー光の代表的な遠視野像 の時間変化を示す. SBSセルへの励起光がない場合, $f=$ $1000 \mathrm{~mm}$ のレンズで集光された He-Neレーザー光のスポッ 卜径は約 $200 \mu \mathrm{m}\left(1 / \mathrm{e}^{2}\right.$ 径 $)$ である。液体媒質の温度に対する 屈折率係数 $\mathrm{d} n / \mathrm{d} T$ 值は負であるので, レーザー光吸収による 放物線型温度分布が発生すると, 負の屈折率分布が生じ凹 レンズ特性を示す。励起開始から約 2 秒後間は熱レンズ効 果により同心円上にスポット径は大きくなるが, セル内の 集光点とその周辺部の温度差により対流が生じ, 円形状か ら棈円状になった。9秒以上では,対流の結果, ビーム変形 は緩和され, スポット形状は変化せず定常状態となった。

繰り返し周波数 $3,5,10 \mathrm{~Hz}$ 時の吸収パワーに対する定常 状態でのスポット径の变化をFig.4に示す。繰り返し周波

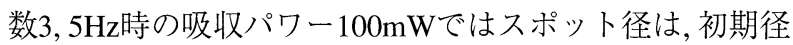
$200 \mu \mathrm{m}$ に比べ最大約 15 倍の $3 \mathrm{~mm}$ 径まで増加し, 集光強度は 約225倍も低下したことになる。繰り返し周波数 $10 \mathrm{~Hz}$ 時 は, $3.5 \mathrm{~mm}$ 程度まで増加した．単一ショット時にはHe-Ne光 の初期スポット径まで回復する緩和時間は $230 \mathrm{~ms}$ 程度であ り, 繰り返し周波数 $4 \mathrm{~Hz}$ 以上になると次のパルス入射時ま でに初期径まで回復しないことになる。よって, 集光付近 の乱れた媒質内に熱拡散時間より速く,繰り返しパルス光 が入射すると.繰り返し周波数が增加するにつれて熱的効 果が顕著となり, スポット径が増加する.

\section{2 集光点の移動による熱光学効果の低減}

前節で述べた封じ切りSBSセルでは,媒質の熱拡散時間 や臨界エネルギーによって入射パワーが制限される。熱

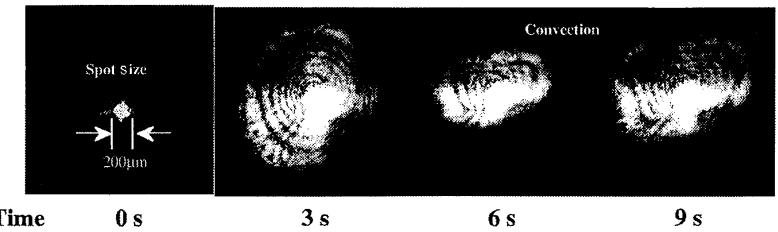

Fig.3 Far-field pattern of defocused He-Ne laser beam. Input energy of $80 \mathrm{~mJ} /$ pulse and repitition rate of 3 $\mathrm{Hz}$ were used.

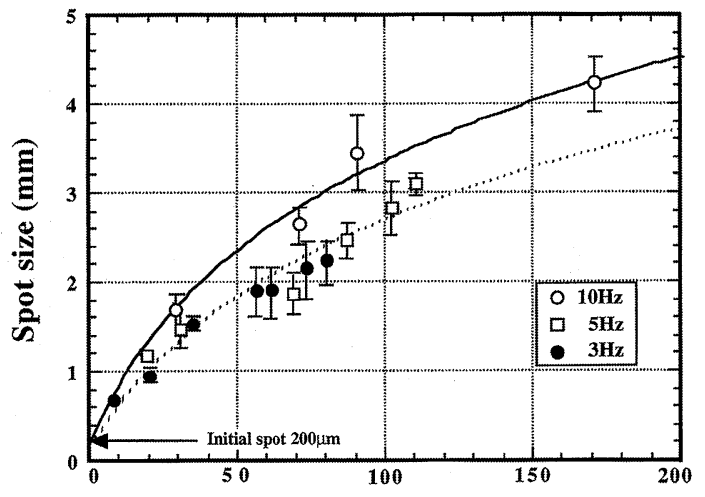

Absorbed power (mW)

Fig.4 Spot size of far-field fidelity as a function of an absorbed power for the different repetition rate.

光学効果を低減する方法として, 集光レンズ前に回転ウ エッジ板を挿入し, 入射パルス毎に集光点位置を移動させ る概念図をFig.5に示す。入射レーザー光は, ウエッジ板の 回転により集光レンズへの入射角が変化するため, 集光点 位置を移動させることができる。

実験配置図はFig.2と同様で, 集光レンズ前に回転ウエッ ジ板を挿入することにより, ビーム集光位置をパルス毎に 変化させ, 熱光学効果の低減実験を行った。 ウエッジ板 は, 口径60mm, ウエッジ角6度のBK-7基板を用い, レーザー 光に対して約45度傾けた. 回転モーター軸はウエッジ板 の中心に固定し, 回転速度は10rpmおよび60rpmとした，集 光スポットの移動半径は5.3mm(円周此離 $33 \mathrm{~mm}$ ) である. 回転速度 $60 \mathrm{rpm}$ の場合の集光点の移動線速度は約 $33 \mathrm{~mm} / \mathrm{s}$ と なり, 繰り返し周波数 $10 \mathrm{~Hz}$ 動作でのパルス間の移動距離は $3.3 \mathrm{~mm}$ である。この值はスポット径 $(200 \mu \mathrm{m})$ の16倍にあた る。

CCDカメラによるHe-Ne光の遠視野像測定結果をFig.6に 示す. Fig.6 (a) は, 励起光を入射しない時, (b) はウエッジ

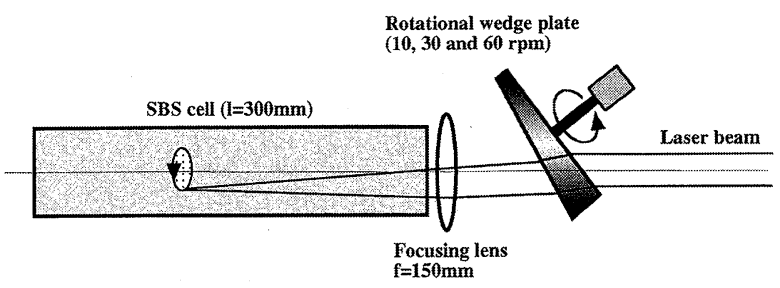

Fig.5 Schematic layout of rotational wedge plate for focal-point displacement. 


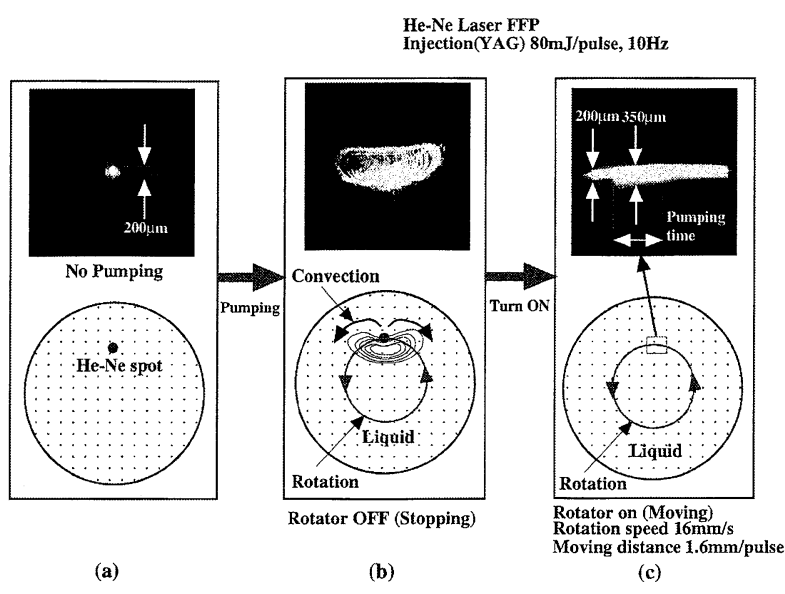

Fig.6 Far-field pattern of defocused He-Ne laser beam with the wedge-plate rotation method.

板を停止し励起光 (入射エネルギー $80 \mathrm{~mJ} /$ パルス, 繰り返し 周波数 $10 \mathrm{~Hz}$ )を入射した時, (c) はウエッジ板を60rpmで回 転させた結果である．Fig.6(b)は,Fig.3の実験結果と同様 に熱拡散効果により, スポット径は下方向に拡がり, 対流 の影響により半円形状となった. Fig.6 (c)ではプローブ光 の円弧軌跡の一部を観測したとき, 入射直後のプローブ光

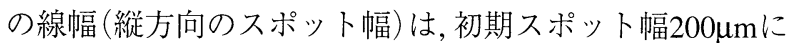

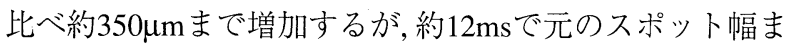
で回復することから, 約 $83 \mathrm{~Hz}$ まで動作可能である。

平均吸収パワーに対する最大スポット径の変化をFig.7 に示す。ウエッジ板を停止時のHe-Ne光の遠視野像は, 最 大吸収パワー約 $170 \mathrm{~mW}$ の時, $X$ 軸方向のスポット径は, 初期 径約 $200 \mu \mathrm{m}$ の約 20.5 倍の $4.1 \mathrm{~mm}$ まで増加した。一方, ウエッ ジ板を60rpmで回転した場合, 最大吸収パワー約 $170 \mathrm{~mW} の$ 時のスポット径は約1.7倍の約 $350 \mu \mathrm{m}$ まで低減した．Y軸方 向の歪みが小さく出ているのは, 対流効果であって, ビー ムパターンの半分は強い屈折を受けて受光されていな い.

ウエッジ板の回転により, 熱歪効果を大幅に抑制するこ とが確認できたので, 単一縦モードQスイッチYAGレー ザー光を用いて, 回転ウエッジ板によるSBS反射率特性の 改善実験を行った.SBS励起用レーザー光は, パルス幅

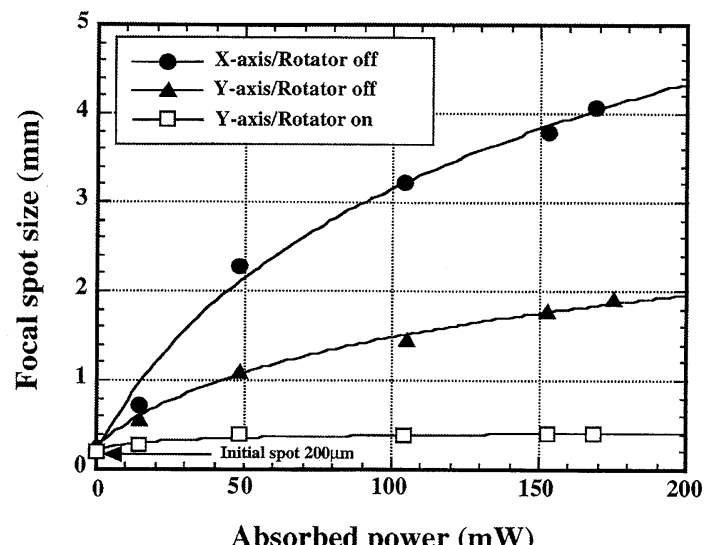

Fig.7 Spot size of far-field fidelity as a function of absorbed power with the wedge-plate rotation.
$25 \mathrm{~ns}$, 出力パルスエネルギー約 $10 \mathrm{~mJ}$ で最大繰り返し周波数 $45 \mathrm{~Hz}$ (平均入力パワー $450 \mathrm{~mW}$ )である. Fig.8に入射パルス の繰り返し周波数に対するSBS反射率特性を示す。単一 ショット時のアセトンのSBS反射率は入射エネルギー $10 \mathrm{~mJ}$ では53\%であった。ウエッジ板の回転を停止した場 合, SBS 反射率は繰り返し周波数 $2 \mathrm{~Hz}$ から急激に低下し, 6Hz以上ではSBS反射は観測されなかった。

一方, ウエッジ板の回転数 $10 \mathrm{rpm}$ の場合, 繰り返し周波数 $25 \mathrm{~Hz}$ 以上ではSBS反射は観測されなかった。初期反射率を $53 \%$ とすると, ウエッジ板の回転停止時および $10 \mathrm{rpm}$ と 60rpmの繰り返し周波数に対する反射率の低下率は, それ ぞれ $9.5,2.0,0.32 \% / \mathrm{Hz}$ となり, 回転数 $60 \mathrm{rpm}$ でのSBS反射率 が1割低下する繰り返し周波数は, $30 \mathrm{~Hz}$ と予想される。回 転数と反射率低下率の積は約 $1.95 \pm 0.02 \mathrm{rpm} \cdot \% / \mathrm{Hz}$ 一定で あった。回転数 $1000 \mathrm{rpm}$ での低下率は $1.95 \times 10^{-3} \% / \mathrm{Hz}$ と予 想され，反射率の相対值で $10 \%$ 低下を使用限界とすると， $270 \mathrm{~Hz}$ 程度までの繰り返し入力に有効である，熱緩和時間 が $12 \mathrm{~ms}(80 \mathrm{~mJ}$ 入) であると, それ以内に次のパルスが入る と熱蓄積効果が出る。即ち, $83 \mathrm{~Hz}$ 以上でみられる。

Fig.9は,レーザーの繰り返し周波数を変えて計測した集 光点のパルス移動距離に対するSBS反射率特性を示す。集

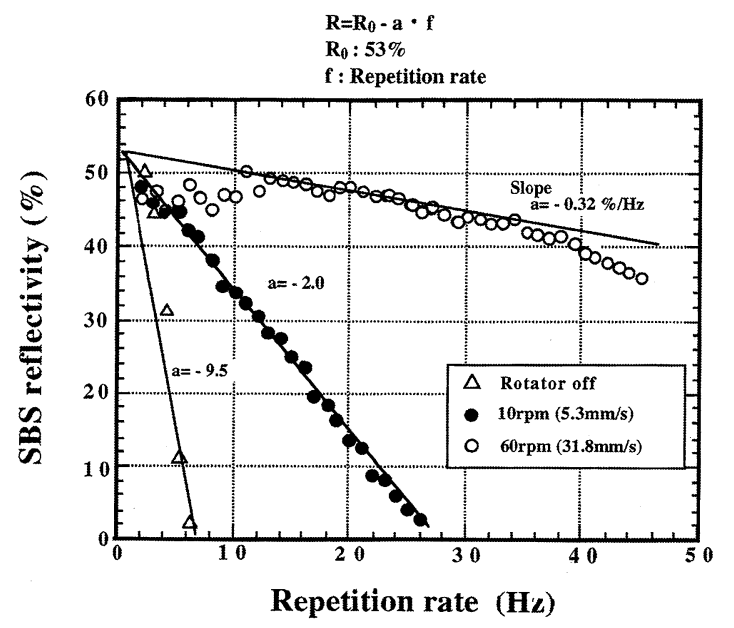

Fig.8 SBS reflectivity as a function of repetition rate for the different rotation speed.

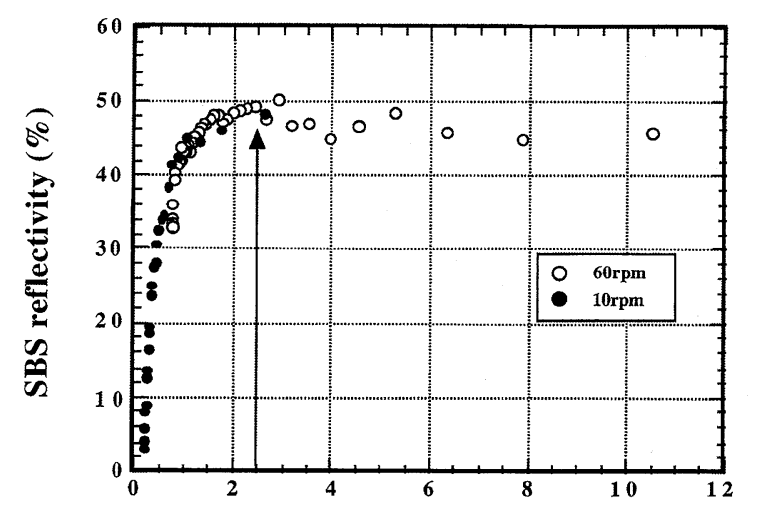

Moving distance of focal spot between pulses ( $\mathrm{mm}$ )

Fig.9 SBS reflectivity as a function of moving distance between focal spots. 
光点の移動距離が約 $2.5 \mathrm{~mm}$ 以上あれば反射率は低下しない 事から, 回転数を 1000rpmで動作させた場合, 移動速度は約 $523 \mathrm{~mm} / \mathrm{s}$ であり, 反射率は約 $200 \mathrm{~Hz}$ までは一定であると考え られる。よって, 集光スポットの移動半径を拡大し, 回転 数を増加する事により kHzオーダーのSBS位相共役鏡は可 能であることがわかる、だだし,パルス位置が1回転した時 に前にパルスの入射した位置と一致する様な場合は, 蓄積 効果により特性劣化が生じるので注意が必要である。

\section{3 液体循環型SBSセルによる熱光学効果の低減}

繰り返しレーザーによるSBS液体の熱蓄積効果にも対応 できるフロー型セルを開発した。循環可能なSBSセルの概 念図をFig.10に示す.ガラス製セルの内径 $20 \mathrm{~mm}$, 長さ $200 \mathrm{~mm}$, 空から集光点までの距離は約 $95 \mathrm{~mm}$ であり, 集光部

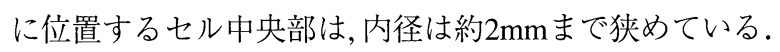

液流による集光位置の流速は, 絞らない形状に比べ約100倍 以上速くなるため, 効果的に熱除去が可能となる. しかし ながら, 25cc/min. 以上の流量では, 媒質が細いセル中央部 を通過した後, 内径の広がる部分で, キャビテーション現 象が生じた。このため, 液体の流量は, 3.6, 14.4, 23cc/ $/ \mathrm{sec} に$ ついての集光スポット径の変化を測定した. 励起用レー ザーを繰り返し周波数 $30 \mathrm{~Hz}$ で動作させた場合,パルス間の 流量は, $0.12,0.48,0.77 \mathrm{cc} / \mathrm{pulse} ゙$ でる。試験液体媒質には, 吸収係数の大きいアセトンを用いた。

各流量での吸収パワーに対するスポット径の変化を,封 じ切りセル, ウエッジ板回転法と対比した結果も合わせて Fig.11に示す。流量 $0.12 \mathrm{cc} / \mathrm{pulse}$ の場合においても, ウエッ ジ板回転法 (60rpm)に比べ熱拡散効果を抑制できた。流量

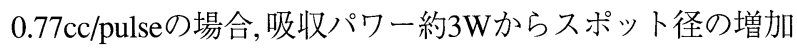
がみられた、スポット強度が $1 / 2$ となる吸収パワーから, 各

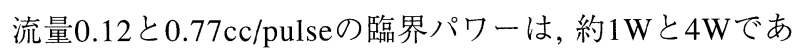
る. 流量 $0.77 \mathrm{cc} / \mathrm{pulse}$ の場合, SBS反射率 $90 \%$ 以上の時, 入射 パワーは約40Wまで可能である. 熱除去を効果的に行うに は,繰り返しパルス間に温度上昇した媒質を押し流す必要

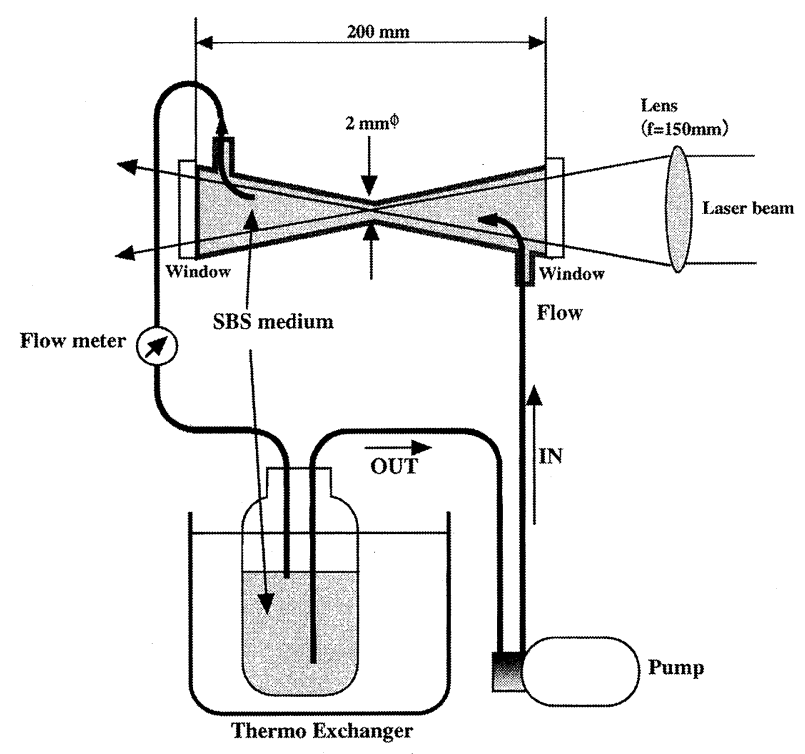

Fig.10 Optical layout of PC mirror with flowing liquid.

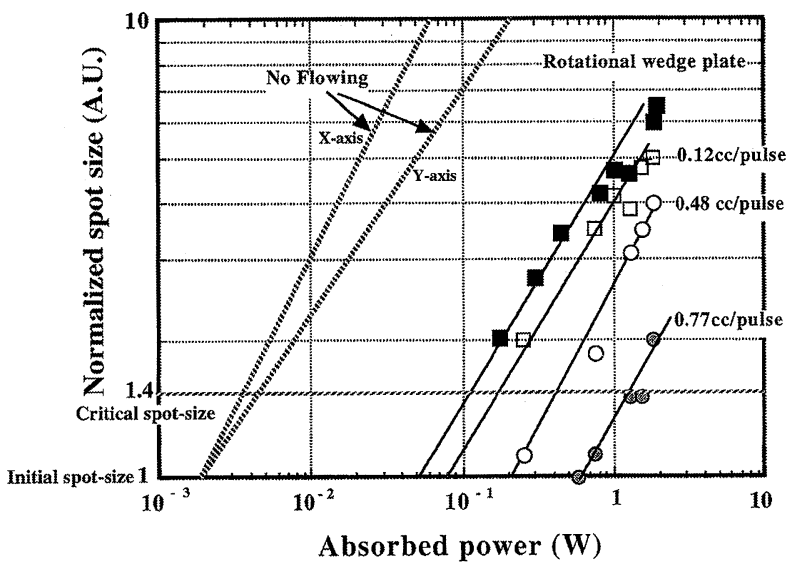

Fig.11 Far-field spot size as a function of absorbed power for the different circulation speed.

がある.今回,試作したセルの相互作用長(レーリー長の約 3倍) と集光部の内径から求めた体積は約 $0.06 \mathrm{cc}$ であり, 繰 り返し周波数 $30 \mathrm{~Hz}$ 時に必要な流量は, $0.06 \mathrm{cc} \times 30 \mathrm{~Hz}=1.8 \mathrm{cc} /$ secである. 流量 $0.77 \mathrm{cc} / \mathrm{pulse}$ での最大繰り返し周波数は, $23 \mathrm{cc} / 0.06 \mathrm{cc}=383 \mathrm{~Hz}$ と予想される。ズル部の形状を最適 化し,キャビテーションを防止することによってkHz級の 動作は容易である。

\section{4. 高平均出力用液体 SBS 位相共役鏡}

本実験では, 高平均出力用SBS位相共役鏡の熱吸収の影 響を観測するため, 波長 $1 \mu \mathrm{m}$ で吸収係数の大きいアセトン を用いた，実用的なSBS位相共役鏡には，取り扱いが容易 で信頼性が高く, 吸収が小さいFC化合物が有効である。 セトンおよびFC-75を同一形状セル内 (内径 $25 \mathrm{~mm}$, 長さ $300 \mathrm{~mm}$ ) に封入して測定した入射パワーおよび吸収パワー に対するスポット径変化量の比較結果をFig.12に示す.ア

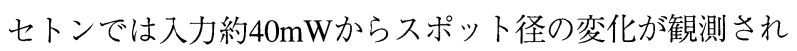
たが, FC-75は入力 $20 \mathrm{~W}$ 程度では, スポット径は変わらな かった。吸収パワーの比較結果から,アセトンの臨界パ ワーは約 $6 \mathrm{~mW}$ であり, 吸収係数と熱物性值から求めた臨界 エネルギー約 $6 \mathrm{~mJ}$ と良く一致している。一方, (1)式より求

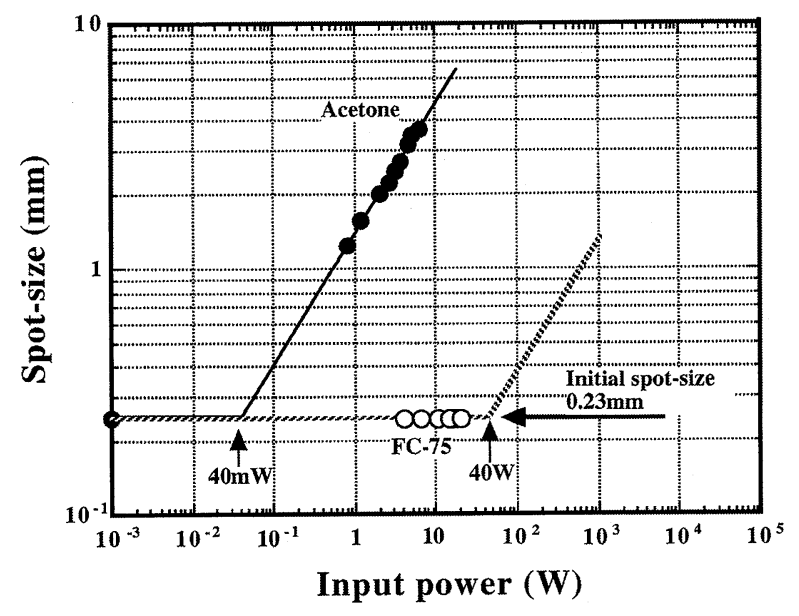

Fig.12 Far-field spot size as a function of input power for acetone and FC-75 liquids. 
Table 1 Estimate of critical incident power to acetone and FC-75 in three types of SBS cell. @ Absorption coefficient at 1- $\mu \mathrm{m}$ wavelength; $2 \times 10^{-2}\left(\mathrm{~cm}^{-1}\right)$ for acetone $3 \times 10^{-6}\left(\mathrm{~cm}^{-1}\right)$ for FC-75

\begin{tabular}{lcccc}
\hline \hline \multirow{2}{*}{ Optical layout } & \multicolumn{2}{c}{ Acetone } & \multicolumn{3}{c}{ SBS materials } \\
& $50 \%$ & $90 \%$ & $50 \%$ & $90 \%$ \\
\hline SBS reflectivity & $20 \mathrm{~mW}$ & $100 \mathrm{~mW}$ & $10 \mathrm{~W}$ & $50 \mathrm{~W}$ \\
\hline Closed cell & $200 \mathrm{~mW}$ & $1 \mathrm{~W}$ & $100 \mathrm{~W}$ & $500 \mathrm{~W}$ \\
$\begin{array}{l}\text { Rotational wedge plate } \\
(60 \mathrm{rpm})\end{array}$ & $8 \mathrm{~W}$ & $40 \mathrm{~W}$ & $4 \mathrm{~kW}$ & $20 \mathrm{~kW}$ \\
$\begin{array}{l}\text { Circulation type } \\
(0.77 \mathrm{cc} / \mathrm{p})\end{array}$ & & & & \\
\hline \hline
\end{tabular}

めたFC-75の全臨界エネルギーは約 $5 \mathrm{~J}(5 \mathrm{~W})$ である。高反射 率動作のSBS位相共役鏡の場合, SBSセルの透過パワーが 臨界パワーを越えない限り，優れたSBS特性が期待でき

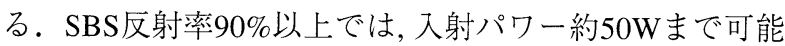
である。

アセトンによる熱光学効果低減実験結果から, FC-75を

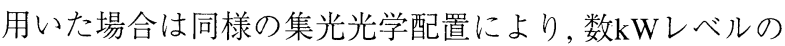
レーザー光に適用できることがわかった、Table 1にアセト ンとFC-75について, 各種光学配置のSBS位相共役鏡での可 能な入射パワーをまとめた．高精度のろ過を施したFC-75 とダストフリーの封じ切りセルは, $1 \mathrm{~J}$ 級, 数 $10 \mathrm{~Hz}$ 動作の市 販Qスイッチレーザーに十分使用可能である ${ }^{14,15)}$. また,

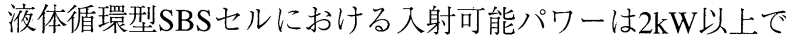
あり, 産業応用パルスレーザーレベルの殆どに利用可能で ある.SBS反射率 $90 \%$ 以上が達成できれば, 入射可能パ

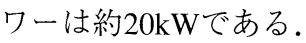

\section{5. まとめ}

高平均出力レーザー光に伴うSBS液体媒質内での相互作 用領域の局所的熱発生によるSBS反射率と忠実度低下の原 因を詳細に調べ,SBS特性を向上させる方法を実験的に検 討した結果について報告した。

SBS液体の励起光による吸収の熱光学効果を軽減する方 法として,（1）ウエッジ回転板による集光点の移動法, (2) 循環フロー型セル法について実験的検討を行った。その
結果, 封じ切りセルに比べ熱拡散効果を大幅に軽減できる ことを確認した．低吸収媒質と循環フロー型セル法の採 用により, 数 $\mathrm{kW}$ 以上のレーザーシステムに適用可能であ る.

\section{参考文献}

1） N. W. Carlson and L. M. Marabella：レーザー学会研究会報告 RTM-96-31 (1996).

2) R. K. Tyson: Principles of Adaptive Optics (Academic press, Boston, 1991).

3) B. Y. Zeldovich: Principles of phase conjugation, Vol. 142 (Spring Verg, 1985).

4) F. J. Roddier：レーザー研究 27 (1999) 78.

5）植田 憲一：レーザー研究 27 (1999) 84.

6) H. Wang : レーザー研究 27 (1999) 89.

7) J. J. Ottusch and D. A. Rockwell: Opt. Lett. 16 (1991) 369.

8) N. F. Andreev, E. Khazanov, and G. E. Pasmanik: IEEE Quantum. Electron 28 (1992) 330.

9）吉田 英次, 藤田 尚德, 吉田 国雄, 山中 龍彦：光学 26 (1996) 31.

10) M. Lefebvre, S. Pfeifer, and R. Johnson: J. Opt. Soc. Am. B.9 (1992) 121.

11) H. Yoshida, V. Kmetik, H. Fujita, M. Nakatsuka, T. Yamanaka, and K. Yoshida : Appl. Opt. 36 (1997) 3739.

12）吉田 英次, 吉田 国雄：レーザー研究 22 (1994) 689.

13）吉田 英次, 中塚 正大：レーザー研究 27 (1999) 95.

14）吉田 英次, 中井 光男, 藤田 尚徳, 宮永 憲明, 中塚 正大, 富永 英 一, 藤野 正志：レーザー学会学術講演会第20回年次大会講演 予稿集 20aI4 (2000) 30 .

15）天野壮, 望月 孝晏, 宮本修治, 安東愛之輔, 細野和彦：レー ザー学会学術講演会第20回年次大会講演予稿集 20aI10 (2000) 33. 